\title{
Já jako učitelka: profesní sebepojetí studentky učitelství v posledním ročníku pregraduální př́ípravy ${ }^{1}$
}

\author{
Blanka Pravdová \\ Masarykova univerzita, Pedagogická fakulta, Katedra pedagogiky
}

Redakci zasláno 8. 10. 2012 / upravená verze obdržena 17. 1. 2013 / k uveřejnění přijato 18. 2.2013

\begin{abstract}
Abstrakt: Studie vymezuje profesní sebepojetí studentky učitelství v závěrečném ročníku pregraduální přípravy. $\mathrm{V}$ textu jsou uvedeny studie věnované problematice sebepojetí a profesního sebepojetí učitele, je doložen význam pozitivního profesního sebepojetí na počátku profesní dráhy a termíny jsou konceptualizovány pro potřebu kvalitativního výzkumu. Obsahová analýza volné výpovědi a hloubkového rozhovoru zaměřená na hledání dominantních aspektů sebepojetí, jeho popis ve vztahu k sebediskrepanční teorii a sledování úvah o možném vývoji profesního Já ukazuje, že nejvýraznějším znakem sebepojetí studentky učitelství jsou obavy pramenící z diskrepance mezi ideálním a skutečným Já, i mezi požadovaným a skutečným Já. Přestože studentka formuluje své učitelské sebepojetí, jeho základy staví na zkušenostech získaných téměř výhradně v roli studenta a žáka. $V$ souvislosti $s$ tímto zjištěním je diskutována otázka, jakým způsobem lze ovlivňovat utváření profesního sebepojetí v rámci pregraduální prípravy studentů učitelství.
\end{abstract}

Klíčová slova: sebepojetí, profesní sebepojetí, učitel, student učitelství, sebediskrepanční teorie

\section{1 Úvodem}

Příspěvek prezentuje první z výstupů kvalitativního výzkumu, jehož cílem je zkoumání možného vlivu metakognitivního nácviku na sebepojetí studentů učitelství. Text se zaměřuje na sebepojetí studentky učitelství 2. ročníku navazujícího magisterského studia Filozofické fakulty Ostravské univerzity. Cílem studie je vymezit pojmy sebepojetí a profesní sebepojetí učitele; popsat průběh a výsledky kvalitativního výzkumu věnujícího se sebepojetí studentky učitelství pro střední školy v závěru její vysokoškolské přípravy a diskutovat tato zjištění v souvislosti s koncepcí pregraduální přípravy učitelů.

1 Tento článek vznikl v rámci projektu Osvojování tacitních znalostí studenty učitelství v průběhu jejich pedagogické praxe (13-20049S) financovaného Grantovou agenturou České republiky. Autorka děkuje za poskytnutou podporu. 


\section{Teoretická východiska}

Sebepojetí je pojmem, jemuž se věnuje jak sociální psychologie, tak psychologie osobnosti. Počátky zkoumání sebepojetí spojujeme s dílem Jamese (1890), jenž odlišil dva aspekty Já: Já poznávající (I-self) a Já poznávané a poznané (Me-self). ${ }^{2}$ Na jeho práci navázali Cooley (1902), Mead (1925) a Allport (1937). Mezi významné přehledové studie věnované tématu sebepojetí patří studie Wylieové $(1974,1979)$, Markusové a Wurfové (1987). U nás se tomuto tématu věnovali např́iklad Říčan (1970), Papica (1985), Bokorová (1988) nebo Bačová (2000). Z novějších zahraničních přehledových studií je možno uvést práce Tessera, Felsona a Sulse (2000); Learyho a Tangneyho (2003). Pro potřeby studie je nutné zmínit s tématem sebepojetí související sebediskrepanční teorii Higginse (1987) a české studie věnované tématu sebepojetí: Sebesystém, vztah $k$ vlastnímu Já (Macek, 2008), Sebepojetí z pohledu sociálně-kognitivní psychologie (Blatný, 2010) a Já a jeho základní struktury a funkce (Vágnerová, 2010a).

Mezníkové studie věnované formální profesní socializaci probíhající v průběhu profesní př́ípravy se v zahraniční odborné literatuře objevily na konci 50. let 20. století. Rané studie byly kontroverzní, přicházely s odlišnými výsledky vypovídajícími o povaze a výstupech profesní přípravy (Merton, Reader, \& Kendall, 1957; Becker et al., 1961). Burns (1989) uvádí, že studií věnovaných úloze a vývoji sebepojetí v učitelském vzdělávání není mnoho. V posledních desetiletích však zájem o problematiku vývoje studentského a profesního sebepojetí učitelů roste, a to jak mezi americkými a západoevropskými výzkumníky (Bullough, Knowles, \& Crow, 1989; Burns, 1989), tak mezi psychology australskými (Carpenter \& Byde, 1994), ruskými (Sidorenko, 2000; Kenžina, 2006) či čínskými (Zhang, 2010). Některá výzkumná zjištění byla publikována jako výsledky spolupráce vědců amerických a ruských (Mandelman et al., 2010). Z českých vědců se tématu věnovali např. Heřmanová (2004), Lukášová-Kantorková (2003) či Lazarová a Jůva (2010).

Zde připomeňme Kantovu transcendentální diferenci. Immanuel Kant rozlišil empirické Já (Já představované, poznávané, posuzované) neboli předmět poznávání a transcendentální Já (Já představující si, poznávající, posuzující) neboli subjekt, jenž se vymyká možnosti objektivizace. Kant jej označuje jako transcendentální podmínku empirického Já (srov. Anzebacher, 1991, s. 107). 


\subsection{Sebepojetí}

Blatný (2010, s. 107) uvádí tuto obecně sdílenou definici: „sebepojetí je souhrnem představ a hodnotících soudů, které člověk o sobě chová". Papica (1985) charakterizuje sebepojetí takto:

Sebepojem je složitým konstruktem implikujícím kognitivní strukturu, ač ne výlučně, pozůstávající z verbálně nebo sémanticky zakódovaných generalizací, do nichžseintegrují novéúdaje a snad taképro subjekt specificky důležitébehaviorální vzorky. Tato zevšeobecnění zahrnují vlastnosti, schopnosti, vědomosti, hodnoty, postoje a sociální role, všechno, čím se subjekt definuje a zhodnocuje. Jsou to především ty charakteristiky, které považuje za sebeprofilující, a na nich závisí, jak bude s jakoukoli personální informací naloženo. (Papica, 1985, s. 19)

Vzhledem ke složitosti konceptu sebepojetí a variabilitě náhledů na něj uvádíme pouze ta pojetí, která považujeme pro výzkumný záměr za klíčová. Podle Blatného (2010) lze rozlišit tyto aspekty sebepojetí (self-concept): kognitivní (struktura, obsah), emoční (sebehodnocení), konativní (seberegulace). V souvislosti s kognitivním aspektem Já je nutné charakterizovat obsah sebepojetí (který se vytváří v procesu socializace a je u každého člověka jiný, nebot' je dán jeho osobní zkušeností) a jednotlivé reprezentace Já. Jednou z nich jsou možná Já (possible selves) Markusové a Nuriusové (1986), skrze něž individuum nahlíží na své možnosti a uvažuje o možných variantách vývoje Já. Možná Já může jedinec vidět jak v rovině ideální, tedy ta Já, jimiž by se rád stal (oblíbené Já, úspěšné Já), tak v rovině obávané, tedy možná Já, k nimž by dospět nechtěl (depresivní Já, nekompetentní Já). Ogilvie (1987) pracuje s termínem nežádoucí Já (undesired self) a chápe jej jako protiklad ideálního Já. V souvislosti s kognitivním aspektem sebepojetí dále Blatný (2010, s. 123) uvádí termín jasnost sebepojetí, který definuje jako „míru, do jaké jsou obsahy sebepojetí jasně a přesvědčivě definovány, jak jsou vnitřně konzistentní a časově stabilní", a komplexitu sebepojetí, kterou chápe jako „bohatství jednotlivých aspektů Já, jimiž se člověk definuje (hodnoty, cíle, role), a jejich vyvážené rozložení do různých oblastí osobního zájmu a důležitosti“.

Ve vztahu k emoční složce sebepojetí jsou zmiňovány zdroje a aspekty sebehodnocení. Higgins (1987) formuloval teorii diskrepancí v sebepojetí (selfdiscrepancy theory), v níž konfrontuje emoční stavy jedince a jeho sebereflexi. Tato teorie souvisí jak s emočním, tak konativním aspektem sebepojetí. Higgins pracuje s pojmy: skutečné Já (actual self), ideální Já (ideal self) a požadované Já (ought self). Ideální Já zahrnuje naše přání, touhy, předsta- 
vy o tom, jací bychom chtěli být. Požadované Já pramení z naší představy o tom, co se po nás žádá, tedy z úkolů, povinností a nároků, jež jsou na nás kladeny a s nimiž se identifikujeme. Skutečné Já reprezentuje ty atributy, o nichž je jedinec přesvědčen, že jimi disponuje. Existuje-li diskrepance mezi Já požadovaným a Já skutečným, prožívá jedinec úzkost, napětí, znepokojení. Nastane-li rozpor mezi skutečným Já a ideálním Já, projevuje se v emočním stavu jedince jako nespokojenost, zklamání a smutek. Jednotlivé složky sebepojetí by měly být v souladu. Podle Vágnerové (2010a) se za užitečnou považuje pouze taková míra diskrepance, která nepůsobí jedinci závažné emoční problémy, nebot' pak může být tato diskrepance motivem k rozvoji sebepojetí. Jako důležité aspekty sebehodnocení jsou uváděny pozitivita či negativita a stabilita sebehodnocení.

Konativní aspekt sebepojetí zahrnuje sebereprezentace, jež se vztahuje k naší potřebě sebejistoty, případně potvrzení vlastní hodnoty. Ve vztahu k problematice seberegulace je považována za významnou role tzv. osobních (či vlastních) standardů, tedy jak uvádí Blatný (2010, s. 129): „norem, cílů a aspirací, jež jsou hlavními měřítky sebehodnocení a pohnutkami chování". Tyto standardy se mohou proměňovat. Př́činou jejich proměny může být srovnávání s jinými, životní zkušenost, nová životní situace nebo změněný sociální kontext. Bandura (1999) uvádí, že motivaci pro naplňování svých standardů získává jedinec prostřednictvím srovnávání skutečného a požadovaného Já. Konceptualizaci sebepojetí lze rozšíriit - s odkazem na knihu ruského literárního vědce Michaila Bachtina Problemy poetiki Dostojevskogo (1963) - o narativní hledisko. Významu Bachtinovy knihy pro psychologii se věnovaly Vasil'eva (1988) a Florenskaya (1989), které dokazují, že Bachtinovy myšlenky přispěly k porozumění dialogické povaze Já. ${ }^{3}$

Dialogické Já je koncipováno jako sociální. Míníme tím nikoli skutečnost, že jedinec vstupuje do sociální interakce s jinými lidmi, nýbrž to, že ostatní lidé zaujímají pozice $\mathrm{v}$ jeho vícehlasém Já.

Podle Bachtina (1963) vytvořil Dostojevský novou formu uměleckého vyjádření - polyfonní román. Romány Dostojevského nemají jediného autora, nýbrž autorů několik. Např. Raskolnikova, Myškina, Stavogina, Ivana Karamazova či Velkého inkvizitora. Každý z těchto hrdinů má svůj vlastní hlas, svůj názor. Hrdina není pouze předmětem Dostojevského umělecké vize, působí jako autor vlastní ideologie. Podle Bachtina neexistuje množství postav v rámci jednotného objektivního světa osvětleného Dostojevského vizí, nýbrž pluralita perspektiv a světů: polyfonie hlasů. Stejně jako v polyfonní skladbě - různé hlasy a nástroje mají odlišné polohy a doprovázejí ostatní nebo jim oponují v dialogickém vztahu. 
Já pohybující se v prostoru a čase zaujímá řadu pozic, které mu umožňují vytvářet vzájemné dialogické vztahy. Jamesem formulovaný rozdíl mezi $I$ a $M e$ je převeden do rámce vyprávění, v němž $I$ je autorem a $M e$ narativní postavou, protagonistou př́iběhu. Jednotlivé postavy (tedy různá $M e$ ) si jako odlišné hlasy vyměňují informace. Výsledkem je komplexní, narativně strukturované Já. V takto probíhajícím dialogu je tedy obsažen pohled jiných osob, stojících vně Já.

Vnímáme-li Já jako vyprávění nebo příběh, zdůrazňujeme tak jeho časovou a vývojovou dimenzi. Podle Scheibeho (1986) jsou př́běhy vypovídající o vlastní identitě zakotveny v konkrétním kulturním prostředí, využívají specifické slovní zásoby a gramatiky daného jazyka, vycházejí z dobových konvencí, přesvědčení a hodnotového systému. Ačkoliv tyto př́běhy využívají základní, univerzální formu vyprávění, způsob a styl, jakým je lidé naplňují obsahem, závisí na historických konvencích př́íslušné doby a místa.

Hermans et al. (1992) uvádějí, že dialogické Já může být zcela pochopeno pouze tehdy, jsou-li uznávány jeho kulturní vazby, nebot' je zakotveno v historickém kontextu, jenž má zásadní význam nejen pro obsah příběhů a dialogické procesy, ale i pro jejich formu.

Crites (1986, s. 162) označil sebepojetí jako druh estetické konstrukce vytvořené z životních zkušeností narativním způsobem. Crites (1986) dále hovoří o narativně strukturovaném vzpomínajícím Já a zdůrazňuje jeho význam pro sebepoznání. S narůstajícími zkušenostmi se minulost stává více než pouhou posloupností událostí, jimiž procházíme, a tvoří tak důležitou část našeho sebepojetí. Pokud však vzpomínající Já neplní úlohu sebeobjevující a integrující, zažívá člověk pocit neštěstí nebo beznaděje. Potlačuje-li jedinec svou minulost, snaží-li se od ní odpoutat, ztrácí svoji identitu.

Právě narativně strukturovaná jednota našeho života jako celku nám umožňuje získat osobní identitu a odpovědět na otázku: „Kdo jsem?“ V př́běhu vlastního Já jsou epizody každodenního života propojeny s motivy morálními a etickými.

Heidegger (podle Polkinghorneho, 1991) zmiňuje dvě možnosti: stát se autorem svého př́běhu, nebo se nechat unášet životem podle scénáře vytvořeného ostatními. Toto „autorství vlastního Já“ chápe jako odpovědnost za děj vlastního života a za realizaci rozhodnutí a opatření $\mathrm{k}$ tomuto ději směřujících. Dosažení narativní integrity událostí našeho životního příběhu je stálým úkolem, někdy dokonce bojem. Bojujeme se vším, co narušuje soudržnost př́běhu. 
Naše životy mohou být naplněny činnostmi a diskuzemi, ale přesto prázdné co do smyslu. Nejsme-li schopni vytvořit sjednocené Já, zůstává náš život roztříštěný. Chceme-li prožívat život jako smysluplný celek, měli bychom své Já chránit před jeho rozpadem na jednotlivé části.

\subsection{Profesní sebepojetí učitele}

Kelchtermansův (1993) koncept profesního Já odlišuje retrospektivní a prospektivní dimenzi. Retrospektivní člení na čtyři části: deskriptivní (selfimage), hodnotící (self-esteem), motivační ${ }^{4}$ (job motivation) a normativní (task perception). Prospektivní dimenze má podle autora jen jednu podobu, a to jsou očekávání, jež učitel vztahuje ke svému profesnímu vývoji.

Mareš etal. (1996, s. 27) navrhují rozšíření prospektivní dimenze o další podobu - o učitelovo vidění perspektiv dalších aktérů pedagogického procesu. Rovněž Kelchtermansův koncept rozšiřuje o třetí dimenzi - akutální profesní Já.

Podle Lazarové a Jůvy (2010, s. 45) zahrnuje sebepojetí učitele „např mínění o sobě jako učiteli, pocity vázané k vlastnímu výkonu, vnímanou pracovní pozici a roli, osobní zkušenost a př́iběh vztažený k práci apod." LukášováKantorková (2003, s. 93) definuje sebepojetí učitele jako „komplexní vnitřní proměnnou, která ovlivňuje každodenní vyučovací činnost učitele, ale zároveň se v ní může i proměňovat", a navrhuje nahlížet sebepojetí učitele $\mathrm{z}$ několika zorných úhlů:

jako míru ztotožnění s expertními požadavky profese učitele; jako prožívání sebe sama v roli a činnosti učitele; jako vnímání sebe sama v roli a činnosti učitele; jako poznání sama sebe, přemýšlení o sobě v učitelské roli a činnosti ve výuce; jako rozhodování o sobě v učitelské roli a vyučovací činnosti; jako uvažování o sociálních podmínkách, jež vytvářím pro učební činnost žákủm. (s. 93)

Přestože je profesní sebepojetí relativně stálým konceptem, v průběhu života dochází $\mathrm{k}$ jeho proměnám, které mohou souviset $\mathrm{s}$ nárůstem zkušeností i informací o sobě samém. Carpenter a Bydeová (1994) ve své longitudinální studii ${ }^{5}$ prokázali odlišnost vývoje profesního sebepojetí mezi studenty uči-

Mareš (1996, s. 26) užívá pro tuto podobu termín snahová.

Předmětem výzkumu byli studenti tř́letého denního programu Učitelství, a to jak oborů pro základní, tak pro střední školy. Data týkající se jejich profesního sebepojetí byla sbírána čtyři roky: od prvního týdne, který strávili na univerzitě, až po závěr prvního školního roku, kdy již působili jako učitelé ve školách. Pro sběr dat byly využity dotazníky a opakovaná skupinová interview. 
telství pro základní a střední školy. Zásadní vliv na utváření pedagogického sebepojetí studentů učitelství pro základní školy měla pedagogická praxe, zatímco akademická výuka byla pro jejich profesní vývoj shledána jako nepř́liš užitečná. Naopak studenti učitelství pro střední školy vnímali vysokoškolskou výuku příznivě. Chápali ji jako základ, díky němuž získávali sebejistotu jako odborníci. Na vývoj profesního sebepojetí této skupiny učitelů měla největší vliv spolupráce $s$ učitelem $v$ rámci pedagogické praxe, ovšem při splnění těchto dvou podmínek: spolupracující učitel poskytl studentovi učitelství potřebnou míru autonomie a současně mu umožnil opírat se o jeho rady a doporučení.

Kenžina (2006) ve svém výzkumu, realizovaném na Orenburské státní univerzitě s 215 studenty pedagogických oborů, dokládá nedostatečnou úroveň zformování pedagogického sebepojetí budoucích učitelů v podmínkách tradiční univerzitní př́ípravy. Na základě výsledků experimentu však zdůrazňuje, že vzdělávací proces na univerzitě vytváří řadu podmínek pro formování učitelského sebepojetí nezbytných, např́klad dialogickou interakci mezi studenty, umožňující jim osvojovat si logické a smysluplné formy diskuse, společné reflektivní činnosti směřující studenty učitelství ke kritickému vnímání informací apod.

Položme si otázku, proč by mělo být sebepojetí učitele na počátku profesní dráhy jasně a zřetelně zformováno, ba co víc: proč by studentovo vnímání sebe sama jako učitele mělo být pozitivní. Bullough (1991) uvádí, že pro profesní růst začínajícího učitele je třeba, aby získal jasný obraz sebe jako učitele. Vstupuje-li učitel do pedagogických situací s nejasným profesním sebepojetím, bývá v pokušení vymezovatsebe sama v reakcinaškolní prostředí a jiné učitele, skrze vztahy a interakce, které ve škole vznikají. V případech, kdy učitelé vnímají sebe sama pouze očima jiných, mohou trpět profesním zklamáním, frustrací a nepřátelstvím vưči žákům i kolegům. S podobným závěrem přichází i Kaganová (1992), která nedostatečně zformovaný obraz sebe sama jako učitele zmiňuje jako častou př́činu neúspěchu v profesi. Ve své studii přináší zjištění, že začínající učitelé vstupují do praxe, aniž by se v průběhu jejich pregraduální př́ípravy změnilo jejich učitelské sebepojetí.

Bullough (1991) publikoval případové studie učitelů, jimž dobře definované profesní sebepojetí pomohlo ujasnit si, jak pojímat svou výuku, jak se chovat ve třídě a především - jak jednat se žáky. Důraz na utváření pozitivního profesního sebepojetí klade i Sidorenko (2000), který upozorňuje na skutečnost, 
že učitelé často nejsou schopni přijímat pozitivně sebe ani ostatní. Chybí jim empatie, prožívají úzkost a nejistotu, neumějí adekvátně emočně reagovat na problémy ve složitých, nepředvídatelných situacích. Ve svém experimentálním výzkumu Sidorenko (2000) dokládá, že pozitivní sebepojetí budoucího učitele se může rozvíjet za předpokladu přiblížení jednotlivých aspektů studentova skutečného Já a jeho Já ideálního. Rozvoj pozitivního sebepojetí budoucího učitele lze tedy považovat za profesně významný. Je-li učitel schopen respektovat sám sebe nejen jako osobnost, ale i jako profesionála, je motivován k trvalému sebezlepšování a profesnímu růstu.

\section{Kvalitativní výzkum: profesní sebepojetí studentky učitelství v posledním ročníku pregraduální přípravy}

\subsection{Cíle výzkumu a výzkumné otázky, vztah výzkumníka ke zkoumanému subjektu}

Hlavním úkolem výzkumu bylo hledání odpovědi na otázku: Jak lze charakterizovat profesní sebepojetí studentky učitelství v závěrečném ročníku studia? Vzhledem ke složitosti konceptu profesního sebepojetí byl zvolen kvalitativní přístup, jenž umožňuje získat podrobný popis a vhled při zkoumání jedince, navíc zkoumá fenomén v prirozeném prostředí (Hendl, 2008, s. 50).

Z výše uvedených charakteristik sebepojetí a profesního sebepojetí učitele vyplynula potřeba analyzovat sebepojetí studentky učitelství ve vztahu k jeho pozitivitě či negativitě, to znamená zabývat se možnými diskrepancemi mezi jednotlivými reprezentacemi Já a vyjádřit míru souladu mezi skutečným Já a jeho variantami. Ve vztahu ke konceptům sebepojetí a profesního sebepojetí učitele byly proto formulovány tyto dílčí výzkumné otázky: Které aspekty profesního sebepojetí studentky učitelství v posledním ročníku studia jsou dominantní? Jak lze popsat sebepojetí studentky učitelství ve vztahu $k$ sebediskrepanční teorii? Jakým způsobem uvažuje studentka učitelství o možném vývoji svého profesního Já?

Výzkum realizovala autorka textu, působící jako středoškolská učitelka českého jazyka a společenských věd fakultní školy Ostravské univerzity, jejíž hodiny navštěvují studenti učitelství v rámci obecně didaktických i oborových náslechů a vykonávají pod jejím vedením závěrečnou pedagogickou praxi. ${ }^{6}$

6 Na Ostravské univerzitě je $\mathrm{v}$ navazujícím magisterském studiu učitelských oborů pedagogická praxe realizována jako tzv. průběžná praxe v 1. ročníku NMgr. studia a jako 


\subsection{Metodologie - sběr a zpracování dat}

Pro diagnostiku sebepojetí bývají využívány sebepopisné dotazníky a škály zachycující vědomý názor jedince na sebe sama, např. Rosenbergova škála sebehodnocení (Rosenberg, 1965, podle Blatný, 2010), Self-Competence/ Self-Liking-Scale (Tafarodi \& Swan, 1995, podle Vágnerové, 2010b) nebo třídicí techniky, např. Q-třídění (Rogers, 1951, podle Blatný, 2010). U těchto výzkumných metod je nevýhodou, že výroky, škály a otázky jsou voleny výzkumníkem a odpovědi respondentů tak nemusí vždy odpovídat jejich skutečnému vnímání vlastního Já. V souladu s tvrzením, že pro zkoumání obsahu sebepojetí je nejspolehlivější přímá subjektivní výpověd' (Macek, 2008, s. 96), byla ke sběru dat využita metoda volné výpovědi (McGuire \& McGuire, 1981, podle Blatný, 2010), jež dotazovaného nesvazuje tím, co o zkoumaném jevu předpokládá výzkumník. Studentka učitelství byla požádána, aby volně formulovala odpověd' na otázku: Jaká jsem Já jako

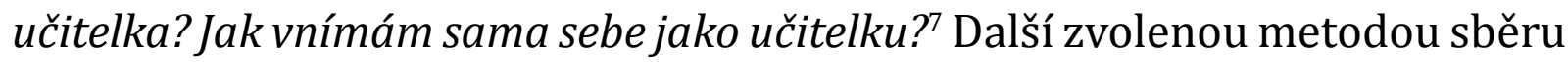
dat byl nestrukturovaný hloubkový rozhovor (Švaříček \& Šed'ová, 2007, s. 159). Výzkumník vycházel z úvodní otázky: Máte nějakou ideální představu o sobě jako učitelce? a dále se dotazoval na základě informací poskytnutých probandkou. I v tomto případě bylo postupováno tak, aby byl co nejméně

tzv. souvislá závěrečná ve 2. ročníku NMgr. studia. V průběhu průběžné praxe se studenti formou náslechů učí pozorovat, analyzovat a hodnotit jednotlivé hodiny, srovnávat práci vyučujících na různých typech středních škol (tzv. „,kolečko“) a samostatně pak vyučují jednu až dvě vyučovací hodiny v každém předmětu aprobace pod vedením oborového didaktika a fakultního učitele. Souvislá závěrečná pedagogická praxe trvá 4 týdny a pro studenta znamená 20 hodin přímé výuky v každém předmětu aprobace. Vyučujícího, pod jehož vedením bude praxi realizovat, si student učitelství může zvolit samostatně.

7 V rámci předvýzkumu byla otázka položena dvěma pětičlenným skupinám studentů. Obě skupiny vykazovaly shodné znaky (studenti učitelství pro SŠ v posledním ročníku studia, studenti motivovaní $\mathrm{k}$ výkonu učitelské profese, stejná délka dosavadní pedagogické praxe). První skupina měla svou odpověd’ formulovat písemně v limitu 45 minut, druhá měla možnost si odpověd' promyslet a zaslat ji výzkumníkovi v písemné podobě elektronicky. Všech pět účastníků první skupiny formulovalo své profesní sebepojetí na několika řádcích, cítili se úkolem zaskočeni, hovořili o nedostatku času, o potřebě zamyslet se nad souvislostmi, vyjadřovali nespokojenost s textem, který odevzdali. Členové druhé skupiny formulovali své odpovědi v různém rozsahu (jedna až tři strany textu), všechny odpovědi obsahovaly charakteristiku vlastního profesního sebepojetí. Respondenti druhé skupiny výzkumníkovi sdělili, že jim formulace nečinila potíže a že jsou se svými odpověd'mi spokojeni. Reakce studentů učitelství účastnících se předvýzkumu byly do značné míry ovlivněny tím, že se po celou dobu pregraduální př́ípravy s úkolem, aby formulovali své profesní sebepojetí, nesetkali. Na základě těchto skutečností byla respondentce dána možnost odpověd' si promyslet a zaslat ji výzkumníkovi v písemné podobě e-mailem. 
ovlivňován obsah formulací a informace o sebepojetí studentky učitelství nebyly zkresleny. Hloubkový rozhovor, jenž trval 45 minut, byl zachycen na audiozáznam a následně přepsán. ${ }^{8}$ Jako závěrečná metoda sběru dat bylo zvoleno otevřené zúčastněné pozorování studentky učitelství, ${ }^{9} \mathrm{v}$ jehož průběhu autorka pořizovala terénní poznámky. Zúčastněné pozorování studentky učitelství při výuce umožnilo hlubší porozumění oběma textům interpretovaným $v$ rámci obsahové analýzy. Oba texty byly kódovány metodou otevřeného kódování (Hendl, 2008, s. 247). Z kódovaných textů bylo vybráno 156 kódů a ty dále kategorizovány ve vztahu k dílčím výzkumným otázkám (viz obr. 1). Zjištěné vazby mezi jednotlivými kategoriemi jsou vyjádřeny schématem na obrázku 2. K interpretaci byla využita technika „vyložení karet" (Švaříček \& Šed'ová, 2007, s. 226).

\subsection{Jak lze charakterizovat profesní sebepojetí studentky učitelství v posledním ročníku studia?}

Volná výpověd' i hloubkový rozhovor byly analyzovány vevztahu ke třem dílčím výzkumným otázkám. U první z otázek: Které aspekty sebepepojetí studentky učitelství jsou dominantní? byly vymezeny tyto kategorie: obavy; uvědomované nároky na profesi učitele; vlastní standardy; odmítnutí. Při hledání odpovědi na druhou otázku: Jak lze charakterizovat sebepojetí studentky učitelství ve vztahu $k$ sebediskrepanční teorii? byly využity jako kategorie termíny ideální Já (ideal self); skutečné Já (real self); požadované Já (ought self). Pro otázku závěrečnou: Jakým způsobem uvažuje studentka učitelství o možném vývoji svého profesního Já? byl jako kategorie použit termín možná Já (possible selves) a rozdělen na dvě subkategorie: ideální možná Já (ideal possible selves) a nežádoucí možná Já (undesired possible selves) - viz obr. 1.

Vzhledem $\mathrm{k}$ tomu, že si studentka učitelství vybrala vyučující, u níž bude vykonávat závěrečnou praxi, sama, na základě osobní zkušenosti, byla komunikace mezi respondentkou a výzkumníkem od počátku otevřená a vstřícná, studentka učitelství hovořila bez obav, nečinilo jí obtíže vyjadřovat se i ke skutečnostem osobního rázu.

9 Zúčastněné pozorování probíhalo ve 20 hodinách českého jazyka a literatury, jež studentka vyučovala v rámci souvislé závěrečné pedagogické praxe na šestiletém gymnáziu. 


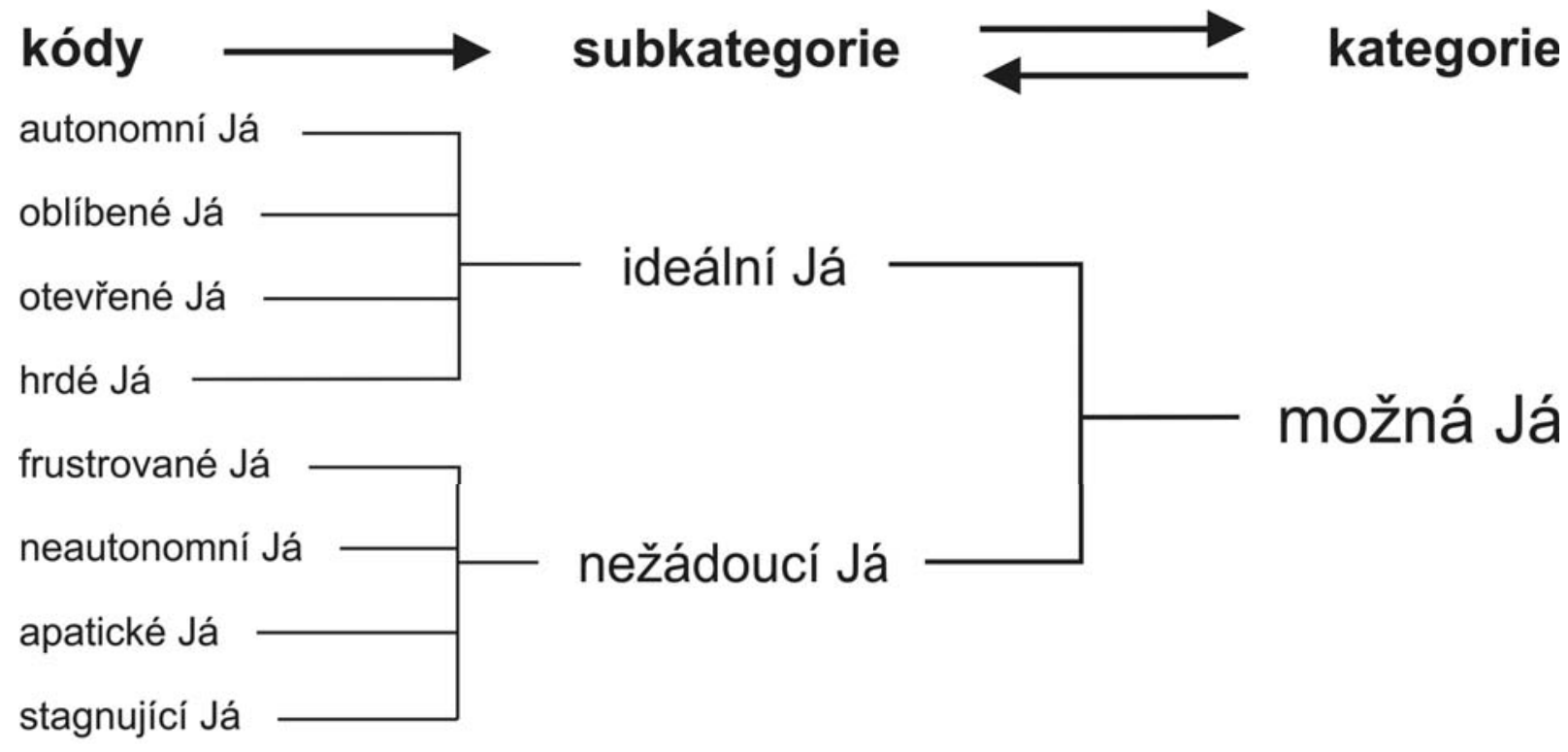

Obrázek 1. Možné reprezentace Já - ukázka sdružování kódů do subkategorií.

3.3.1 Které aspekty sebepojetí studentky učitelství jsou dominantní? Jak lze charakterizovat sebepojetí studentky učitelství ve vztahu $k$ sebediskrepanční teorii?

Vzhledem ke zjištěným vazbám mezi jednotlivými kategoriemi (obr. 2) byla formulace odpovědí na první dvě otázky propojena a kategorie interpretovány společně. Ve vnímání sebe sama jako učitelky dominují u studentky učitelství obavy. Ty pramení nejen z uvědomění si vlastních nedostatkủ či slabých stránek, ale i z náročnosti zvolené profese. Požadované Já je tvořeno atributy, o nichž je jedinec přesvědčen, že by jimi měl - na základě pohledu významných jiných (jimiž jsou v tomto případě žáci, rodiče žáků, vedení školy či kolegové) - disponovat. Studentka si uvědomuje řadu úkolů a povinností, jejichž plnění je od ní očekáváno.

Studentka rovněž, vědoma si nároků kladených na profesi učitele, formuluje vlastní standardy, jejichž naplnění považuje pro úspěšný výkon své profese za důležité. Výrazněji než vědomí jaká jsem učitelka, však vystupuje do popředí povědomí o tom, jaká nechci být učitelka, tedy odmítnutí některých alternativ vývoje profesního Já i konkrétních metod práce či způsobů komunikace. Studentka své profesní Já definuje v opozici vůči svým středoškolským zkušenostem. 
Obavy pramení na jedné straně z neznalosti některých postupů a mechanismů souvisejících s učitelskou profesí, na straně druhé vycházejí z poměrně zevrubné obeznámenosti s rozsahem činností, jimiž je učitel nucen se zabývat. Obavy vztahující se k úrovni vlastní odbornosti mají dvě podoby. U němčiny jako prvního oboru se jedná o strach z nevyužití získaných znalostí a dovedností: „Skončím někde na zemědělském učilišti a mé vědomosti mi budou k ničemu.“; z odborné stagnace: „Bojím se toho, že zakrním.“ U druhého oboru - tedy češtiny - se jedná o obavu opačného rázu: „Mám obavu z toho, že nebudu v obraze."; dále o obavu z neschopnosti reagovat na vývoj v oboru: „Stále se rodí noví autoři, stále vydávají nové sbírky, budu stíhat sledovat tyto trendy?" či obavu z konkrétních nezvládnutých celků učiva: „Jak mám pak vyučovat např. antickou literaturu, když jsem ji naposledy měla v 1. ročníku na SŠ a to jen letem světem? Jak mám učit ruské autory, když se na VŠ neprobírají a na SŠ jsme je zmínili jen autor, dílo, tj. telefonní seznam autorů a jejich děl?“; obavu ze selhání před žáky: „Deprimuje mě fakt, že nikdy nebudu vědět vše, že mě budou studenti moct dostat, někdo si např́klad doma po večerech čte nějakého estonského nebo mad’arského autora, ale jak ho mám znát já?“ S tím souvisí i další z vyjádřených obav: „Budu mít chut’ se stále a stále vzdělávat?"

S obavou o udržení či získání požadovaného stupně odbornosti souvisejí i studentčiny obavy vztahující se k časové náročnosti profese. Opakovaně zmiňuje obavu z nedostatku volného času: „Budu mít nějaký volný čas na rodinu, nebude tento čas na úkor kvality mých hodin?" a z toho vyplývající obavu z nástupu do profese: „Mám hrůzu z toho prvotního náporu, který na mě dolehne, až začnu skutečně učit." Zde studentka předjímá situaci, která nastává u řady začínajících pedagogů a v odborné literatuře (viz Korthagen et al., 2011, s. 47) je označována jako šok z reality (reality shock) nebo šok $\mathrm{z}$ přechodu do praxe (transition shock). Studentka nastiňuje jakýsi, z jejího pohledu, začarovaný kruh: chce-li vykonávat svou práci dobře, musí se pečlivě připravovat, což znamená nastudovat problematiku, s níž se v průběhu vysokoškolského studia (ani přes svůj svědomitý přístup) nesetkala. Předpokládá, že se to projeví na nedostatku volného času. Pokud by však na důkladnou přípravu rezignovala, je přesvědčena, že by se její profesní vývoj ubíral jiným směrem, než si představuje.

Studentka uvádí řadu činností, které by měl učitel zvládat, nastiňuje schopnosti a dovednosti, jimiž by měl, na základě očekávání - jak laiků, tak odbor- 
níků - učitel disponovat, a mnohé z nich současně vnímá jako vlastní standardy. Řadí mezi ně i potřebu hmatatelného výsledku vlastního učitelského působení: „... aby měli něco $v$ sešitech; ... že něco žákům předám.“ Klade ji do souvislosti s potřebou kvalitních didaktických pomůcek: „Když pracuji se špatnou učebnicí, která nedostatečně akcentuje určité věci, tj. nedostatečné množství cvičení na probíranou gramatiku, málo otázek k textu, přemíra poslechů aj., poté musím knihu odložit a vytvořit si vlastní přípravu." Vlastní standardy studentky učitelství jsou vymezeny poměrně obsáhle. Zmiňuje rovněž potřebu přehodnocovat vlastní postoje. I přes své veskrze negativní zkušenosti, jež získala s prací ve skupinách (ještě v roli žákyně), říká: „Nemohu však na základě své špatné zkušenosti s prací ve skupinkách tuto organizační formu výuky zcela zavrhnout."; je si vědoma svého profesního vývoje, růstu: „Moje osobnost učitele se vyvíjí.; zmiňuje potřebu vyvarovat se postupů a způsobů jednání, jež považuje za nesprávné: „Mám svá předsevzetí, jaká bych nechtěla být.“; nutnost reflexe získaných zkušeností: „Ta mi ukáže [zkušenost - pozn. autora], do jaké hloubky a co je třeba skutečně znát." Učitel by měl být (podle studentčina sebepojetí) schopen prosazovat pluralitu ve výuce: „V podstatě neexistuje návod jak číst a vnímat literární dílo.“; být schopen vést žáky vlastním př́íkladem $\mathrm{k}$ pluralitě názorů: „Jsem otevřena ke konfrontacím a argumentacím; každý má právo vidět v něm [v literárním díle - pozn. autora] něco jiného."

Za své přijímá i některé postoje, jež považuje u učitele za samozřejmé: odpovědnost vůči žákovi: „Studenti za hloupý systém na OU nemohou; ... aby nedokonalostmi učebnice netrpěli studenti.“; pozitivní vztah k oboru: „Literatura mi přirostla k srdci a je tomu tak i dnes. Neznám nic horšího, než když učitel svůj obor nesnáší a dává to žákům najevo."; motivovanost k výkonu profese: „Nepatř́m k lidem, kteří se rozhodli studovat pedagogickou či filozofickou fakultu jen proto, jelikož nevěděli, kam mají jít. Rozhodla jsem se pro filozofickou fakultu se zcela jasným cílem: učit na SŠ." Uvědomuje si i další nároky kladené na učitele a opětovně je vztahuje $\mathrm{k}$ vlastním standardům. Například schopnost budování bezpečné atmosféry ve třídě: „Každý má právo na svůj názor; ... aby se skutečně nebáli zeptat a neměli strach ze zesměšnění nebo odmítnutí z mé strany." či snahu o otevřenou komunikaci se žáky: „Chtěla bych jim také dát prostor na debatu se mnou." Studentka tak skrze své vlastní standardy definuje své ideální Já, jež do značné míry ztotožňuje s nároky kladenými na učitele, tedy s požadovaným Já. 
O obsahu nežádoucího Já svědčí výčet jevů, jež studentka striktně odmítá. Většina pregnantně formulovaných odmítnutí má svůj původ v negativních zkušenostech $\mathrm{z}$ dob vlastního vzdělávání, $\mathrm{v}$ menší míře pak pramení ze zkušeností získaných $\mathrm{v}$ průběhu náslechů $\mathrm{v}$ hodinách cvičných učitelů. Jako učitelka se chce vyhnout konkrétním didaktickým nedostatkům: „... přenášení svých povinností na studenty - tj. celou hodinu zabít ,odfláknutými' referáty a takto postupovat hodinu co hodinu..."; chybám v komunikaci se žáky: „... přenášení osobních nezdarů a špatné nálady na studenty a průběh hodiny; neustálý nátlak na premianty; neschopnost dodržet před celou třídou vyřčené závazné sliby...“; nedostatku pedagogického taktu: „... opovržlivé hlasité komentování špatné známky u premianta; preferování některých žáků na úkor jiných...; postupům, které žáky demotivují: „motivace strachem; neohlášené testy $\mathrm{v}$ časovém presu s hlasitým odpočítáváním; absolutní subjektivita při ústním zkoušení vyzdvihovaných jedinců; podhodnocování žáků průměrných a podprůměrných..." či chybám výchovným. Studentka svá odmítnutí směřuje i k intolerantním postojům žáků: „Budu tolerantní, pokud však tento názor nebude urážlivý vůči okolí, menšinám a náboženství." $\mathrm{S}$ konkrétními předobrazy z minulosti souvisí i odmítnutí autokratického typu učitele: „Nejsem zastáncem přístupu: já jako učitel vím vše nejlíp a vy jen sed'te a bez otázek a myšlení akceptujte, co ř́kám." Studentka odmítá i negativní pocity: „Nechci trpět pocitem méněcennosti.“

3.3.2 Jakým způsobem uvažuje studentka učitelství o možném vývoji svého profesního Já?

Své odhodlání směřovat vývoj profesního Já k pozitivnímu vnímání sebe sama promítá studentka do představy oblíbeného Já: „Myslím, že někteří [žáci] mě budou mít rádi.“; motivujícího Já: „,... aby do mé hodiny chodili strašně rádi, těšili se třeba...“; otevřeného Já: „Pokusím se dát žákům prostor na dotazy a vytvořit takovou atmosféru, aby se skutečně nebáli se mě zeptat a neměli strach ze zesměšnění nebo odmítnutí z mé strany.“; hrdého Já: „Co bych si teda přála - nevím, jestli to pořád funguje - to jsou takové ty olympiády a soutěže. Přála bych si připravit na to některé studenty, kteří by dobrovolně chtěli a kteří by díky tomu byli úspěšní. Tak bych si strašně přála připravit toho studenta a pak být hrdá a byla by to moje vizitka, že to nějaký student dokázal.“

Vyslovuje však i možná nežádoucí Já: apatické Já; odborně stagnující Já: „Zakrním, budu apatická a znechucená. A toho bych se nechtěla dožít." Dále 
vyslovuje i obavy z vývoje směrem $\mathrm{k}$ Já neautomnímu a frustrovanému: „A ona [vyučující němčiny - pozn. aut.] ř́kala, že tady stejně nemá žádnou pravomoc, žádné slovo, že ten $s$ vyšším titulem a větší praxí prostě rozhodne vždycky o všem, jestli se koupí CD přehrávač a podobně. A z toho bych byla asi taky frustrovaná, až budu hotová a nebudu mít žádnou pravomoc." V souvislosti s tím se dotýká i otázek morálních: „Tohoto já se strašně bojím, že budu mít ve třídě nějakého sígra, a jak jsu taková spravedlivá, že s tím nebudu moct nic dělat. Že prostě mi ředitel řekne: ty ty ty, ten bude mít dvojku, ten nám tu školu sponzoruje, my ty peníze potřebujeme...; Já právě nevím, jak bych na to reagovala, kdyby to bylo jednou, možná bych to unesla, ale kdyby se to stávalo víckrát, tak nevím, jestli bych u té profese setrvala. Mě to vevnitř strašně frustruje, mě to uvnitř úplně rve, když vidím něco nespravedlivého, když vidím, že někdo má navrch úplně neprávem."

\subsubsection{Shrnutí}

Skutečné Já studentky učitelství lze charakterizovat prostřednictvím dominantních aspektů, skrze něž je formulován obsah jednotlivých reprezentací Já: kategorie odmítnutí - nežádoucí Já, uvědomované nároky na profesi učitele - požadované Já, vlastní standardy - ideální Já, obavy - nežádoucí Já (viz obrázek 2).

diskrepance

diskrepance

protiklad

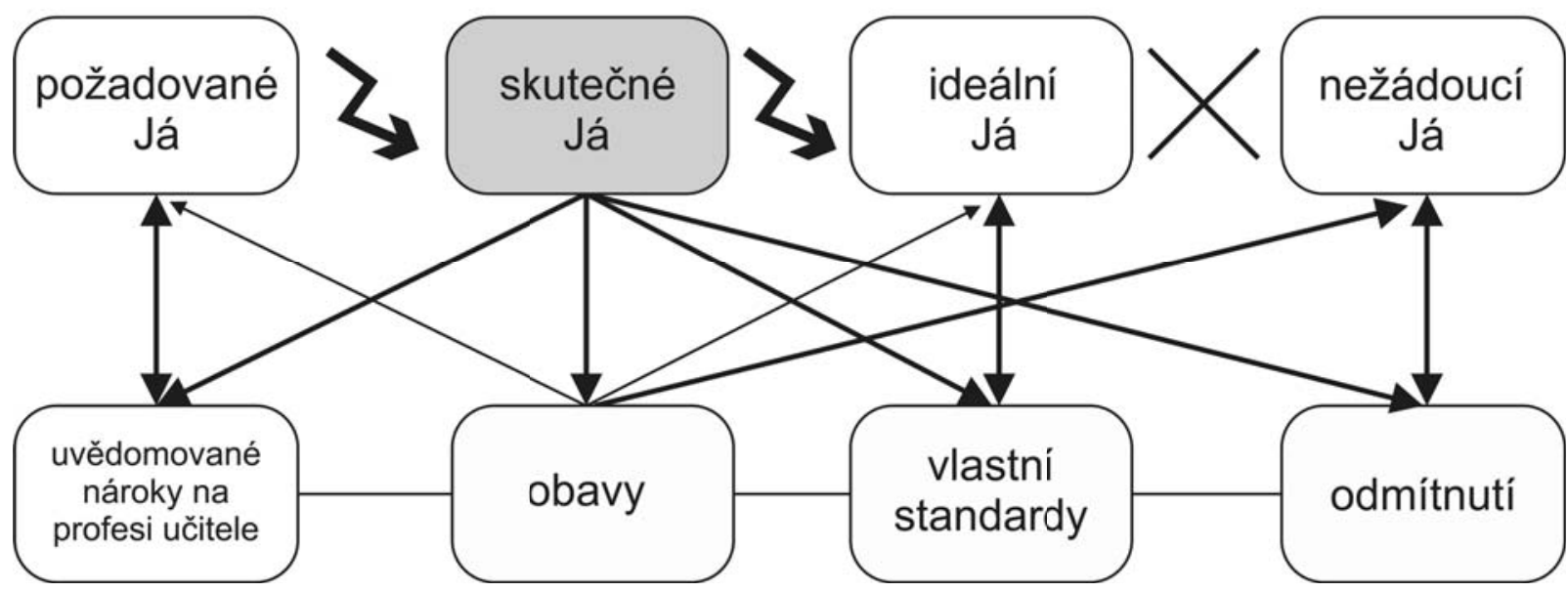

Obrázek 2. Sebepojetí studentky učitelství - vyjádření vztahů mezi kategoriemi. 
Výrazným znakem profesního Já studentky učitelství jsou obavy pramenící z rozporu nejen mezi ideálním a skutečným Já, ale i mezi požadovaným a skutečným Já. Pocity nejistoty a úzkosti vyplývající z této diskrepance jsou vyjádřeny jako stupňovaná obava (děsím se; mám hrůzu) a promítají se do možných nežádoucích reprezentací Já.

Studentčiny obavy souvisejí se ztotožněním uvědomovaných nároků na profesi učitele. Tyto nároky studentka včleňuje do vlastních standardů, jež se pak promítají do její představy ideálního Já. Se studentčinou potřebou přiblížit skutečné a ideální Já souvisí nejen obsah nežádoucího profesního Já (jako protikladu Já ideálního), ale i odmítnutí těch postupů a okolností, jež by k němu mohly směřovat.

\section{Závěry a diskuse}

Formulacevýzkumných otázekvycházelazpředpokladu,žejednou zpodmínek pro úspěšný výkon učitelské profese je pedagogovo pozitivní profesní sebepojetí. Uvědomění si skutečnosti, že mám-li být jako učitel spokojen, je nutné prožívat ve vztahu ke své profesi, k žákům, ale i k sobě samotnému emoce pozitivní, se jeví jako podstatná součást profesního sebepojetí. Proto lze jako významné označit studentčino odmítnutí negativních pocitů. Studentka zvažuje možné varianty svého profesního vývoje a formuluje jak ideální možná Já: oblíbené Já, motivující Já, otevřené Já, hrdé Já, tak nežádoucí možná Já: apatické Já, odborně stagnující Já, neautonomní Já, frustrované Já. Ve shodě se závěry Ogilvieho (1987) tak staví do protikladu nežádoucí a ideální Já.

Ačkoliv studentka učitelství zřetelně formuluje obsah nežádoucího profesního Já, svou představu o tom, kudy by se měl ubírat její profesní vývoj, nemá prozatím zcela ujasněnu. Její potřeba být oblíbenou a tolerantní učitelkou, která alespoň některé studenty dobře připraví a do jejíchž hodin budou žáci chodit rádi, je pochopitelná, ale nemusí být v řadě pedagogických situací tím správným vodítkem.

I když vlastní standardy vymezuje poměrně náročně, je patrné, že vychází především z negace zkušeností získaných v roli studentky či žákyně, což sama komentuje slovy: „Moje osobnost učitele se vyvíjí v opozici k mým středoškolským zkušenostem." Většinu svých představ a postojů vztahovaných k profesnímu Já konfrontuje s Já minulým - vrací se k negativním zážitkům, 
hovoří o křivdách, které vnímá jako důležité pro utváření svého profesního Já: „Její hodiny jsem nenáviděla. Dodnes si některé její komentáře pamatuji i ten můj pocit bezmoci. Něco obdobného se dělo některým spolužákům v jiných předmětech. Slíbila jsem sama sobě, že takto nikomu ubližovat nebudu. Nebudu se nad žáky povyšovat a zesměšňovat je před třídou." Zde se nabízí odkaz na Korthagena et al. (2011, s. 253), jenž poukazuje na „potřebu vést studenty učitelství k reflexi příběhu jejich vlastního života a způsobu, kterým se utvářela jejich přesvědčení a sebepojetí jako učitele“.

Výzkumná zjištění ruských psychologů (Kenžina, 2006; Sidorenko, 2000) dokládají, že vývoj profesního sebepojetí budoucího učitele lze ovlivňovat již od počátku vysokoškolského studia. Ztotožňují se tak s Bulloughovým tvrzením (podle Korthagena et al., 2011, s. 253), že „vzdělávání učitelů musí začínat zkoumáním vlastního učitelského Já". V této souvislosti je nutné konstatovat, že $s$ úkolem, aby se zamýšlela nad svým profesním Já, se studentka setkala poprvé v posledním ročníku studia, a to nikoli v rámci vysokoškolské přípravy na budoucí profesi, nýbrž prostřednictvím účasti na tomto výzkumném šetření.

Ptáme-li se, jakým způsobem lze ovlivňovat utváření profesního sebepojetí v rámci pregraduální př́ípravy studentů učitelství, nabízí se př́ístup pedeutologů (Carpenter \& Byde, 1994; Píšová, 2005; Korthagen et al., 2011), kteř́i na základě vlastních výzkumných nálezů kladou důraz na dlouhodobou praktickou př́ípravu budoucích učitelů přímo ve školách, a to včetně průběžné reflexe, jež je supervidována vysokoškolskými učiteli.

Na tomto místě je třeba zmínit zájem, s nímž studentka s autorkou studie sdílela své komplexní zkušenosti získané v rámci předchozí pedagogické praxe (20 hodin výuky německého jazyka). Přestože zmiňovaná praxe a výzkum probíhaly s několikaměsíčním odstupem, o řadě skutečností, s nimiž se studentka $v$ prủběhu praxe setkala, hovořila poprvé až při hloubkovém rozhovoru. Jednalo se přitom o situace, které vyžadovaly hlubší reflexi a hledání možných alternativ jejich řešení.

Nejen v průběhu pedagogické praxe, ale již od počátku pregraduální př́ípravy vzniká řada situací, které umožňují studentům učitelství konfrontovat své náhledy na učitelskou profesi s vlastním Já. Domnívám se, že právě absence pravidelné a cílené reflexe (a z ní vycházející sebereflexe), jsou příčinou toho, že tyto př́ležitosti zůstávají často nevyužity. 
Jsou-li v rámci vysokoškolské výuky reflektovány a odborně rozvíjeny zkušenosti, které studenti učitelství získali jak v roli žáka, tak prostřednictvím vlastních učitelských zkušeností, je cesta jak k hledání vhodných alternativ vlastních pedagogických postojů, profesního jednání, tak i k utváření pozitivního profesního sebepojetí budoucího učitele otevřena. Kenžina (2006) navrhuje jako jednu z cest k ovlivňování pozitivního profesního sebepojetí studentů učitelství realizaci speciálního kurzu Formování pedagogického sebepojetí budoucího učitele, jehož obsah funkčně propojuje teorii s praxí a rozvíjí u studentů učitelství reflektivní dovednosti, které podporují formování jeho pozitivního profesního sebepojetí.

Jako další možnost, jak ovlivňovat sebepojetí studentů učitelství se jeví metakognitivní nácvik probíhající po dobu pedagogické praxe. Jádrem nácviku je reflexe vlastního učení podporovaná supervizorem. Krykorková a Chvál (2001) citují zahraniční výzkumy, které hodnotí účinnost metakognitivního nácviku u různých skupin žáků a potvrzují pozitivní změny osobnostního charakteru, jež se týkaly sebepojetí žáků, vztahů se spolužáky nebo změny v př́istupu k neúspěchu a selhání. Na otázku, zda je možné podobné výsledky očekávat i v př́ípadě podpory metakognitivního myšlení studentů učitelství, bude hledat odpověd' navazující kvalitativní šetření.

\section{Poděkování}

Autorka děkuje oběma anonymním recenzentům za jejich podnětné připomínky.

\section{Literatura}

Allport, G. W. (1937). Personality: A psychological interpretation. New York: Holt.

Anzebacher, A. (1991). Úvod do filosofie. Praha: SPN.

Bačová, V. (2000). Súčasné smery v psychológii. HÍadanie alternatív pozitivismu. Prešov: Prešovská univerzita.

Bachtin, M. M. (1963). Problemy poetiki Dostojevskogo. Moskva.

Bandura, A. (1999). Social cognitive theory: An agentic perspective. Asian Journal of Social Psychology, 2(1), 21-41.

Becker, H. S., Geer, B., Hughes, E. C., \& Strauss, A. L. (1961). Boys in white: Student culture in medical school. Chicago: University of Chicago Press.

Blatný, M. (2010). Sebepojetí z pohledu sociálně-kognitivní psychologie. In M. Blatný, et al., Psychologie osobnosti. Hlavní témata, současné př́stupy (s. 105-136). Praha: Grada.

Bokorová, V. (1988). Význam ego-struktur v psychické a sociální regulaci. Československá psychologie, 32(2), s. 131-141. 
Bullough, R. V. Jr. (1991). Exploring personal teaching metaphors in preservice teacher education. Journal of Teacher Education, 42(1), 43-51.

Bullough, R. V., Knowles, J. G., \& Crow, N. A. (1989). Teacher self-concept and student culture in the first year of teaching. Teachers College Record, 91(2), 209-233.

Burns, R. B. (1989). The self-concept in teacher education. South Pacific Journal of Teacher Education, 17(2), 27-36.

Carpenter, P. G., \& Byde, P. (1994). The development of professional self-concept. Asia-Pacific Journal of Teacher Education, 22(2), 163-176.

Cooley, C. D. (1902). Human nature and the social order. New York: Scribner's.

Crites, S. (1986). Storytime: Recollecting the past and projecting the future. In T. R. Sarbin (Ed.), Narrative psychology: The storied nature of human conduct (s. 152-173). New York: Praeger.

Florenskaya, T. A. (1989). Psychological problems of dialogue in light of the ideas of M. M. Bakhtin and A. A. Ukhtomskii. Soviet Psychology, 27(5), 29-40.

Higgins, E. T. (1987). Self-diskrepancy: A theory relating self and affect. Psychological Review, 94(3), 319-340.

Hendl, J. (2008). Kvalitativní výzkum. Základní teorie, metody a aplikace. Praha: Portál.

Hermans, H. J., Kempen, H. J., Van, L., \& Rens, J. (1992). The dialogical self: Beyond individualism and rationalism. American Psychologist, 47(1), 23-33.

Heřmanová, V. (2004). Profesní sebepojetí učitelů. Ústí nad Labem: Acta Universitatis Purkynianae.

James, W. (1890). The principles of psychology 1-2. New York: Holt.

Kagan, D. M. (1992). Professional growth among preservice and beginning teachers. Review of Educational Research Summer, 6(2), 129-169.

Kenžina, Û. A. (2006). Formirovanie pedagogičeskoj Â-koncepcii buduŝego učitelâ v obrazovatel'nom processe VUZA (Disertační práce). Orenburg: Orenburgskij gosudarstvennyj pedagogičeskij universitet.

Kelchtermans, G. (1993). Getting the story, understanding the lives: From career stories to teachers' professional development. Teaching and Teacher Education, 9(5-6), 443-456.

Korthagen, F., Kessels, J., Koster, B., Lagerwerf, B., \& Wubbels T. (2011). Jak spojit praxi s teorií: Didaktika realistického vzdělávání učitelů. Brno: Paido.

Krykorková, H., \& Chvál, M. (2001). Rozvoj metakognice - cesta k hodnotnějšímu poznání. Pedagogika, 51(2), 185-196.

Lazarová, B., \& Jůva, V. (2010). Učitelé a faktor času: o proměnách pracovního sebepojetí. Studia paedagogica, 15(2), 43-60.

Leary, M. R., \& Tagney, J. P. (Eds.) (2003). Handbook of self identity. New York: Guilford Press.

Lukášová-Kantorková, H. (2003). Učitelská profese v primárním vzdělávání a pedagogická př́prava učitelu․ Ostrava: PdF OU.

Macek, P. (2008). Sebesystém, vztah k vlastnímu Já. In J. Výrost \& I. Slaměník (Eds.), Sociální psychologie (s. 89-107). Praha: Grada.

Mandelman, S. D., Tan, M., Kornilov, S. A., Sternberg, R. J., \& Grigorenko, E. L. (2010). The metacognitive component of academic self-concept: The development of a triarchic selfscale. Journal of Cognitive Education and Psychology, 9(1), 73-86. 
Mareš, J., Slavík, J., Svatoš, T., \& Švec, V. (1996). Učitelovo pojetí výuky. Brno: Masarykova univerzita.

Markus, H., \& Nurius, P. (1986). Possible selves. American Psychologist, 41(9), 954-969.

Markus, H., \& Wurf, E. (1987). The dynamic self-concept: Social psychological perspective. Annual Review of Psychology, 38, 299-337.

Mead, G. H. (1925). The genesis of the self and social control. International Journal of Ethics, 35(3), 251-273.

Merton, R. K., Reader, G. G., \& Kendall, P. L. (Eds.). (1957). The Student-physician: Introductory studies in the sociology and medical education. Cambridge: Harvard University Press.

Miovský, M. (2006). Kvalitativní př́stup a metody v psychologickém výzkumu. Praha: Grada.

Ogilvie, D. M. (1987). The undesired self: A neglected variable in personality research. Journal of Personality and Social Psychology, 52(2), 379-385.

Papica, J. (1985). Sebepojetí, jeho struktura a funkce. In J. Hudeček \& J. Papica (Eds.), Autoregulační mechanismy osobnosti (s. 16-27). Brno: Oddělení psychologie ÚVSV ČSAV.

Píšová, M. (2005). Klinický rok: procesy profesního rozvoje studentů učitelství a jejich podpora. Pardubice: Univerzita Pardubice.

Polkinghorne, D. E. (1992). Narrative and self-concept. Journal of Narrative and Life History, 1(2-3), 135-153.

Říčan, P. (1970). Pojmy já v psychologii osobnosti. Československá psychologie, 14(3), 209-229.

Sidorenko, V. S. (2000). Razvitie pozitivnoj Â-koncepcii buduŝego učitelâ v processe pedagogičeskoj podgotovki $v$ vysšej škole (Disertační práce). Moskva: Institut teorii obrazovaniâ i pedagogiki.

Scheibe, K. E. (1986). Self-narrative and adventure. In T. R. Sarbin (Ed.), Narrative psychology: The storied nature of human conduct (s. 129-151). New York: Praeger.

Švaříček, R., \& Šed'ová, K. (2007). Kvalitativní výzkum v pedagogických vědách. Praha: Portál.

Tesser, A., Felson, R., \& Suls, J. (Eds.). (2000). Psychological perspectives on self and identity. Washington, D. C.: American Psychological Association.

Vágnerová, M. (2010a). Já a jeho základní struktury a funkce. In M. Vágnerová (Ed.), Psychologie osobnosti (s. 298-346). Praha: Karolinum.

Vágnerová, M. (2010b). Metody diagnostiky sebepojetí. In M. Vágnerová (Ed.), Psychologie osobnosti (s. 424-428). Praha: Karolinum.

Vasil'eva, I. I. (1988). The importance of M. M. Bakhtin's idea of dialogue and dialogic relations for the psychology of communication. Soviet Psychology, 26(3), 17-31.

Zhang, X. (2010). The study of university students' self-concept. International Education Studies, 3(1), 83-86.

Wylie, R. C. (1974; 1979). The self-concept (rev. ed.). Lincoln: University of Nebraska Press.

\section{Autorka}

Mgr. Blanka Pravdová, Masarykova univerzita, Pedagogická fakulta, Katedra pedagogiky,

Poŕíćí 31, Brno 603 00, e-mail: pravdova@ped.muni.cz 


\title{
My teacher self: Professional self-concept of a student teacher in the last year of undergraduate training
}

\begin{abstract}
The study describes the professional self-concept of a student teacher in the last year of undergraduate training. The study reflects overview studies dealing with the issue of self-concept and the professional self-concept of the teacher. The importance of positive professional self-concept at the onset of professional development is documented and terms are conceptualized to suit needs of qualitative research. Content analysis of a free utterance and an in-depth interview concentrates on the search for dominating aspects of self-concept, the description of the selfconcept in relation to the self-discrepancy theory and the thoughts about a possible development of the professional self. It shows that the most significant aspect of the student's self-concept is the fear emanating from the discrepancy between the ideal self and the real self, between the ought self and the real self. Despite the fact that the student is formulating her self-concept as a teacher, it is constructed almost exclusively on experience gained in the role of a pupil. Following up this findings, the study discusses the question in what way the forming of professional self-concept should be influenced during the undergraduate teacher training.
\end{abstract}

Keywords: self-concept, professional self-concept, teacher, student teacher, selfdiscrepancy theory

Gavora, P. (2012). Tvorba výskumného nástroja pre pedagogické bádanie. Bratislava: SPN.

Predmetom monografie je spracovanie problematiky tvorby výskumných nástrojov. Zvláštna pozornost'jevenovanáadaptovaniu už existujúcich zahraničných výskumných nástrojov i preto, že v tejto oblasti sa v našich sociokultúrnych podmienkach vyskytujú problémy. Jadrom knihy je opis postupných krokov adaptácie, podporený príkladmi a ukážkami z hotových výskumných nástrojov. Publikáciu odporúčame do pozornosti výskumným a akademickým pracovníkom, ktorí chcú rozšírit' svoje metodologické vedomosti, prípadne stoja pred úlohou vytvorit’ výskumný nástroj alebo adaptovat' niektorý z existujúcich. 